\title{
FAKTOR-FAKTOR YANG MEMPENGARUHI KEBIJAKAN DIVIDEN PADA PERUSAHAAN YANG TERDAFTAR DI BURSA EFEK INDONESIA
}

\author{
YOHANES ERYANTO dan SURYANTO
}

\author{
Trisakti School of Management \\ Yohanes19@gmail.com
}

\begin{abstract}
The purpose of this research is to provide empirical evident whether insider ownership, firm size, profitability, leverage, liquidity, earnings per share and price to book ratio have significant influence of dividend policy. Sample in this research are nonfinancial companies, which are listed in Indonesian Stock Exchange over the three years period 2012 until 2014. This research used purposive sampling method. The sample of this research consist of 52 companies that meet in criteria. This research uses multiple regression analysis to find out the influence of all independent variables above to dividend policy. The result of the research showed that firm size, leverage, earnings per share and price to book ratio had a significant influence on dividend policy, while insider ownership, profitability and liquidity had no influence.
\end{abstract}

Keywords: dividend policy, insider ownership, firm size, profitability, leverage, liquidity, earnings per share, price to book ratio

\begin{abstract}
Abstrak: Tujuan penelitian ini adalah untuk memberikan bukti empiris apakah insider ownership, ukuran perusahaan, profitabilitas, leverage, likuiditas, earnings per share dan price to book ratio memiliki pengaruh yang signifikan terhadap kebijakan dividen. Sampel dalam penelitian ini adalah perusahaan non keuangan, yang tercatat di Bursa Efek Indonesia selama tiga tahun 2012 hingga 2014. Penelitian ini menggunakan metode purposive sampling. Sampel penelitian ini terdiri dari 52 perusahan yang memenuhi kriteria. Penelitian ini menggunakan beberapa analisis regresi untuk mengetahui pengaruh semua variabel independen di atas terhadap kebijakan dividen. Hasil penelitian menunjukkan bahwa ukuran perusahaan, leverage, earnings per share dan price to book ratio memiliki pengaruh signifikan terhadap kebijakan dividen, sedangkan insider ownership, profitabilitas dan likuiditas tidak memiliki pengaruh.
\end{abstract}

Kata kunci: kebijakan dividen, insider ownership, ukuran perusahaan, profitabilitas, leverage, likuiditas, earnings per share, price to book ratio 


\section{PENDAHULUAN}

Dalam perkembangan dunia perekonomian yang global, sebagai pelaku ekonomi perusahaan dituntut untuk mampu bersaing. Perusahaan dituntut untuk dapat tumbuh dan berkembang dalam rangka menjaga kelangsungan hidupnya dan memenangkan persaingan. Perusahaan perlu melakukan investasi untuk meningkatkan pertumbuhan perusahaan. Perusahaan yang sudah go public dapat menarik dana dari investor dengan melakukan jual beli saham secara luas di pasar modal (Harahap 2011). Balas jasa yang diharapkan oleh investor yang berinvestasi dalam bentuk saham adalah dividen (Ismail et al. 2013 dalam Damayanti dan Martiningtiyas 2014).

Kebijakan dividen merupakan bagian yang tidak dapat dipisahkan dengan keputusan pendanaan perusahaan. Kebijakan dividen merupakan keputusan dari manajemen perusahaan untuk menentukan berapa banyak laba yang harus dibagikan kepada para pemegang saham/investor dan berapa banyak yang harus ditanam kembali menjadi laba ditahan (Bansaleng et al. 2014).

Semakin besar dan kompleknya suatu perusahaan maka pemilik tidak mungkin melakukan seluruh fungsi-fungsi manajemen untuk mengelola usahanya. Dengan kondisi seperti itu dan dalam mempercepat pencapaian target yang telah ditetapkan maka pemilik perlu menunjuk agen (manajer) yang profesional (Wedhana dan Wiksuana 2015). Pemegang saham memberikan kepercayaan mereka kepada manajemen untuk mengatur dan mengolah perusahaan demi mencapai tujuannya. Tetapi tidak sedikit terjadi perbedaan pendapat antara manajemen dengan pemegang saham karena perbedaan kepentingan. Perbedaan kepentingan ini menyebabkan timbulnya konflik agensi (agency conflict).

Kinerja keuangan perusahaan menjadi indikator pihak pemegang saham sebagai prestasi kerja. Semakin baik kinerja perusahaan mengindikasikan bahwa semakin bagus prestasi kerja perusahaan sehingga memberikan kepercayaan bagi pihak-pihak yang telah menanamkan modalnya di perusahaan (Kartika dan Suarjaya 2015). Keputusan keuangan yang harus dipertimbangkan dengan baik adalah keputusan investasi, keputusan pendanaan dan kebijakan dividen. Kebijakan dividen merupakan salah satu faktor yang mempengaruhi peningkatan pemberian dana di pasar modal(Rachmad dan Muid 2013).

Penelitian ini mereplikasi penelitian Khalid dan Rehman (2015), dengan menambahkan earnings per share, price to book ratio, leverage, dan likuiditas dari penelitian Kazucu (2015).Tujuan dari penelitian ini adalah untuk memberikan bukti empiris apakah insider ownership, ukuran perusahaan, profitabilitas, leverage, likuiditas, earnings per share dan price to book ratio memiliki pengaruh yang signifikan terhadap kebijakan dividen.

\section{Agency Theory}

Pada agency theory yang disebut prinsipal adalah pemegang saham dan yang dimaksud agen adalah manajemen yang mengelola perusahaan. Tujuan utama perusahaan adalah memaksimumkan kemakmuran bagi pemegang saham. Untuk itu manajer yang diangkat oleh pemegang saham harus bertindak untuk kepentingan pemegang saham, tetapi ternyata sering terjadi konflik diantara manajemen dan pemegang saham. Konflik ini disebabkan karena adanya perbedaan kepentingan antara manajemen dan pemegang saham (Wahidahwati 2002).

Jensen dan Mekling (1976) dalam Ulum (2011) mengemukakan asumsi dalam agency theory bahwa masing-masing individu termotivasi oleh kepentingannya masing-masing sehingga menimbulkan konflik kepentingan antara principal dan agent. Pemilik termotivasi untuk mensejahterakan dirinya dengan profitabilitas yang selalu meningkat, sedangkan 
pihak manajemen termotivasi untuk memaksimalkan pemenuhan ekonomi dan psikologisnya. Masalah ini akan menimbulkan biaya agensi. Biaya agensi yang ditanggung oleh pemegang saham karena kehadiran atau untuk menghindari agency problem (Gitman dan Zutter 2012).

Menurut Watt dan Zimmerman (2003) dalam Ulum (2011) biaya agensi meliputi (1) monitoring cost, yaitu biaya yang dikeluarkan oleh principal untuk mengawasi perilaku agent agar tidak menyimpang dari yang diinginkan oleh pemilik misalnya biaya untuk mengawasi perilaku agent, biaya untuk menyusun sistem kompensasi, (2) Bonding cost yaitu pengeluaran agent untuk menjamin bahwa dia akan bertindak sesuai dengan keinginan principal, misalnya biaya menyewa auditor.

Ada beberapa alternatif yang bisa dilakukan untuk mengurangi biaya agensi yaitu (1) Meningkatkan kepemilikan saham perusahaan oleh manajemen, (2) Mekanisme pengawasan dalam perusahaan,

Meningkatkan dividen payout ratio, (4) Meningkatkan pendanaan dengan hutang (Mayangsari 2000 dalam Indahningrum dan Handayani 2009). Dengan demikian dividen dapat dijadikan alat kontrol untuk mengurangi biaya agensi dan pengawasan terhadap manajer.

\section{Insider Ownership dan Kebijakan Dividen}

Penelitian yang dilakukan oleh Kartika dan Suarjaya (2015), Rachmad dan Muid (2013) serta Karina dan Darsono (2014) menunjukkan bahwa insider ownership memiliki pengaruh yang signifikan dan berhubungan positif terhadap kebijakan dividen. Hal ini disebabkan karena fungsi dari investor dan kreditor sebagai pengawas. Manajer berusaha mempertahankan kualitas kinerja dan tindakan ini menurunkan konflik keagenan (Rachmad dan Muid 2013). Hasil penelitian ini bertentangan dengan penelitian yang dilakukan Khalid dan Rehman (2015) serta Simanjuntak dan Kiswanto (2015) yang menunjukkan bahwa insider ownership berpengaruh negatif terhadap kebijakan dividen. $\mathrm{Hal}$ berarti perusahaan yang memiliki persentase kepemilikan manajerial yang besar akan membayar dividend payout ratio dalam jumlah kecil. Sedangkan pada perusahaan yang memiliki persentase kepemilikan manajerial kecil, akan menetapkan dividend payout ratio dalam jumlah besar (Simanjuntak dan Kiswanto 2015).

Hal ini berbanding terbalik dengan penelitian yang dilakukan oleh Rahmawati (2014) serta Devi dan Erawati (2014) yang mengatakan bahwa insider ownership atau kepemilikan manajerial tidak berpengaruh terhadap kebijakan dividen. Presentase jumlah kepemilikan saham manajerial dan kekuatan pihak manajer yang relatif kecil menyebabkan pemegang saham atau investor tidak mengkhawatirkan perilaku mereka secara berlebihan (Rahmawati 2014).

$\mathrm{H}_{1}$ Terdapat pengaruh insider ownership terhadap kebijakan dividen

\section{Ukuran Perusahaan dan Kebijakan Dividen}

Hasil penelitian yang dilakukan Kazucu (2015) menunjukkan hubunganyang positif antara ukuran perusahaan dengan kebijakan dividen. Dengan demikian, perusahaan yang lebih besar dan dewasa cenderung membayar dividen yang lebih. Hasil ini konsisten dengan penelitian yang dilakukan Devi dan Erawati (2014), Rachmad dan Muid (2013) serta Karina dan Darsono (2014) yang menunjukkan bahwa ukuran perusahaan berpengaruh signifikan dan berhubungan positif terhadap kebijakan dividen.Hal ini bertentangan dengan penelitian yang dilakukan oleh Khalid dan Rehman (2015) yang menunjukkan bahwa ukuran perusahaan memiliki pengaruh yang signifikan dan negatif terhadap kebijakan dividen. Pengaruh negatif ukuran perusahaan menunjukkan bahwa perusahaan memilih untuk menginvestasikan asetnya dari pada membayar dividen, namun besarnya pengaruh kecil yang mungkin 
merupakan indikasi bahwa perusahaan sedang mendekati masa jatuh tempo (Khalid \& Rehman 2015).

Sedangkan menurut Wicaksono dan Nasir (2014), ukuran perusahaan tidak berpengaruh secara signifikan terhadap kebijakan dividen. Hal ini disebabkan karena semakin besar perusahaan maka kesempatan investasi akan semakin besar pula. Dengan banyaknya kesempatan investasi tersebut maka akan lebih baik jika keuntungan yang ada ditanamkan pada investasi yang dapat menghasilkan NPV positif, sehingga perusahaan membayarkan dividen yang rendah.

$\mathrm{H}_{2}$ Terdapat pengaruh ukuran perusahaan terhadap kebijakan dividen

\section{Profitabilitas dan Kebijakan Dividen}

Penelitian yang dilakukan Khalid dan Rehman (2015) menyatakan bahwa profitabilitas memiliki pengaruh signifikan dan positif terhadap kebijakan dividen. Perusahaan yang memiliki profitabilitas yang tinggi dalam hal pengembalian aset memiliki pembayaran dividen yang sesuai dengan pendapatan mereka. Hasil penelitian ini konsisten dengan penelitian yang dilakukan oleh Rachmad dan Muid (2013), Wicaksono dan Nasir (2014) serta Karina dan Darsono (2014).

Hal ini bertentangan dengan penelitian yang dilakukan oleh Sumanti dan Mangantar (2015) serta Wedhana dan Wiksuana (2015) yang menunjukkan bahwa variabel profitabilitas tidak berpengaruh signifikan terhadap kebijakan dividen. Hal tersebut terjadi akibat pada tingkat profitabilitas yang rendah perusahaan tetap membayarkan dividen dan membayarkan dividennya pula pada nilai yang tinggi untuk menjaga reputasi perusahaan tersebut dimata investor. Sebaliknya, pada perusahaan dengan profitabilitas yang tinggi cenderung akan membayarkan dividen rendah untuk mengalokasikannya pada laba yang ditahan untuk kepentingan pada masa yang akan datang (Sumanti dan Mangantar 2015).
$\mathrm{H}_{3}$ Terdapat pengaruh profitabilitas terhadap kebijakan dividen.

\section{Leverage dan Kebijakan Dividen}

Hasil penelitian yang dilakukan oleh Sulistyowati et al. (2014) yang menyatakan bahwa leverage berpengaruh signifikan dengan arah positif terhadap kebijakan dividen. LDTA berpengaruh signifikan dengan arah positif terhadap DPR. Saat LDTA mengalami kenaikan maka DPR akan naik, saat LDTA mengalami penurunan maka DPR akan turun. Saat LDTA mengalami kenaikan maka DY akan naik, saat LDTA mengalami penurunan maka DY akan turun.Hal ini bertentangan dengan penelitian yang dilakukan oleh Bansaleng et al. (2014), Kazucu (2015), Mawarni dan Ratnadi (2014), Devi dan Erawati (2014) serta Rachmad dan Muid (2013) yang menunjukkan bahwa leverageberpengaruh negatif dan signifikan terhadap kebijakan dividen. Hal ini berarti perusahaan yang memiliki tingkat hutang yang rendah akan lebih memprioritaskan kesejahteraan pemegang sahamnya dengan pembagian dividen, sebaliknya jika perusahaan tersebut memiliki tingkat hutang yang besar maka perusahaan akan lebih berkonsentrasi pada pelunasan kewajibannya dibandingkan membagikan dividen (Bansaleng et al. 2014).

Sedangkan menurut Karina dan Darsono (2014) serta Damayanti dan Martiningtiyas (2014) menunjukkan bahwa leverage tidak berpengaruh secara signifikan terhadap kebijakan dividen. Perusahaan yang mempunyai rasio hutang yang tinggi atau rendah tidak akan mempengaruhi besaran pembagian dividen. Hal ini dikarenakan oleh sebaran data penelitian yang terlalu luas sehingga menyebabkan rasio hutang tidak memiliki pengaruh terhadap keputusan kebijakan dividen (Karina dan Darsono 2014).

$\mathrm{H}_{4}$ Terdapat pengaruh leverage terhadap kebijakan dividen. 


\section{Likuiditas dan Kebijakan Dividen}

Likuiditas perusahaan merupakan pertimbangan utama dalam kebijakan dividen, karena dividen bagi perusahaan merupakan kas keluar, maka semakin besar posisi kas dan likuiditas persahaan secara keseluruhan akan semakin besar pula kemampuan perusahaan untuk membayar dividen (Sartono 2001 dalam Rahmawati 2014).

Menurut penelitian yang dilakukan oleh Rahmawati (2014) serta Mawarni dan Ratnadi (2014) menunjukkan bahwa likuiditas berpengaruh positif pada kebijakan dividen. Nilai positif dalam variabel cash ratio ini menunjukkan bahwa adanya peningkatan jumlah kas dan setara kas dalam perusahaan sehingga dapat meningkatkan dividend payout ratio. Meningkatnya cash ratio dapat juga meningkatkan harapan investor terhadap kemampuan perusahaan dalam membagikan dividen (Mawarni dan Ratnadi 2014).

Sedangkan penelitian yang dilakukan oleh Sitanggang dan Agustina (2011), Kazucu (2015) serta Wicaksono dan Nasir (2014) menunjukkan bahwa likuiditas perusahaan tidak mempunyai pengaruh yang signifikan terhadap kebijakan dividen. Hal ini disebabkan karena perusahaan dalam membagikan dividen tidak hanya memperhatikan kondisi likuiditas perusahaan saja tetapi juga memperhatikan lingkungan eksternal perusahaan (Sitanggang dan Agustina2011).

$\mathrm{H}_{5}$ Terdapat pengaruh likuiditas terhada kebijakan dividen.

\section{Earnings per Share dan Kebijakan Dividen}

Menurut penelitian yang dilakukan Harahap (2011), Sitanggang dan Agustina (2011), Abdullah dan Agaki (2014) serta Amyas et al. (2014) menunjukkan bahwa earnings pershare berpengaruh positif pada kebijakan dividen. Semakin besar earnings per share maka akan semakin besar dividen yang dibagikan perusahaan kepada investor, begitu juga sebaliknya. Hal ini mengindikasikan bahwa earnings per share dipertimbangkan oleh manajemen dalam pembayaran dividen kas (Harahap 2011). Hal ini bertentangan dengan penelitian yang dilakukan oleh Kazucu (2015) yang menunjukkan bahwa earnings per share berpengaruh signifikan dan negatif terhadap kebijakan dividen. Pengaruh negatif dari earnings per share masih dapat ditafsirkan sebagai perusahaan dengan pendapatan tinggi (rendah) cenderung menurun (meningkat) payout ratio nya (besarnya dividen relatif dari laba).

Sedangkan penelitian yang dilakukan oleh Singhania dan Gupta (2012) menunjukkan bahwa earnings per share tidak signifikan terhadap kebijakan dividen. Hal ini menunjukkan profitabilitas bukan tingkat penentu yang penting terhadap dividen yang dibayarkan perusahaan.

$\mathrm{H}_{6}$ Terdapat pengaruh earnings per share terhadap kebijakan dividen.

\section{Price to Book Ratio dan Kebijakan Dividen}

Hasil penelitian yang dilakukan oleh Damayanti dan Martiningtiyas (2014) menunjukkan bahwa price to book ratio berpengaruh signifikan dan positif terhadap kebijakan dividen. Saat price to book ratio meningkat, maka peluang investasi juga akan meningkat. Perusahaan-perusahaan dengan peluang investasi yang tinggi akan membayarkan dividen lebih untuk menarik investor dan untuk meningkatkan kepercayaan pemegang saham kepada perusahaan. Hal ini bertentangan dengan penelitian yang dilakukan Singhania dan Gupta (2012) serta Abdullah dan Agaki (2014) yang menunjukkan bahwa price to book ratio berpengaruh signifikan dan negatif terhadap kebijakan dividen.Pada perusahaan pertambangantingkat return saham yang diperolehdigunakan untuk menambah modal sendiri dalam bentuk dana cadangan atau laba ditahan, tidak dibagikan sebagai dividen (Abdullah dan Agaki 2014).

Sedangkan penelitian yang dilakukan oleh Kazucu (2015) menunjukkan bahwa price to 
book ratio tidak berpengaruh signifikan terhadap kebijakan dividen. Tidak signifikannya nilai price to book tidak menyampaikan bukti bagi catering theory, yang hanya menyebut premium dividen sebagia perbedaan antara rasio rata-rata price to book ratio dari dividen yang dibayarkan dan tidak dibayarkan.

$\mathrm{H}_{7}$ Terdapat pengaruh price to book ratio terhadap kebijakan dividen.

\section{METODE PENELITIAN}

Populasi dalam penelitian ini adalah seluruh perusahaan non keuangan yang terdaftar di Bursa Efek Indonesia (BEI) selama periode 2012 sampai dengan 2014. Teknik pengambilan sampel menggunakan metode purposive sampling, yaitu pemilihan sampel dimana informasi yang diperlukan dikumpulkan dari target atau kelompok tertentu (Sekaran dan Bougie 2013). Adapun kriteria-kriteria yang digunakan dalam penelitian ini adalah:

Tabel 1

Prosedur Pemilihan Sampel

\begin{tabular}{lcc}
\hline \multicolumn{1}{c}{ Keterangan } & Sampel & Data \\
\hline $\begin{array}{l}\text { Perusahaan non keuangan yang konsisten terdaftar di BEl dari } \\
\text { tahun 2012-2015 }\end{array}$ & 376 & 1128 \\
$\begin{array}{l}\text { Perusahaan yang tidak menggunakan mata uang rupiah } \\
\text { Perusahaan yang tidak memiliki net income selama periode } \\
\text { penelitian }\end{array}$ & $(77)$ & $(231)$ \\
$\begin{array}{l}\text { Perusahaan yang tidak memiliki kepemilikan manajerial } \\
\text { Perusahaan yang tidak membagikan dividen secara konsisten }\end{array}$ & $(114)$ & $(258)$ \\
selama periode penelitian & $(47)$ & $(141)$ \\
$\begin{array}{l}\text { Jumlah perusahaan yang dijadikan sampel } \\
\text { Data Outlier } \\
\text { Jumlah data akhir yang digunakan dalam penelitian selama tahun } \\
2012 \text { sampai dengan tahun 2014 }\end{array}$ & 52 & 156 \\
\hline
\end{tabular}

Sumber: data yang dikumpulkan

Kebijakan dividen yang diberi simbol DP adalah keputusan apakah laba yang diperoleh perusahaan pada akhir periode akan dibagikan kepada para pemegang saham atau akan ditahan untuk menambah modal guna pembiayaan investasi dimasa yang akan datang (Bansaleng et al. 2014). Kebijakan dividen menggunakan skala rasio dan dihitung dengan membagi dividen dengan earnings (Khalid dan Rehman 2015).

$$
\mathbf{D P}=\frac{\text { Dividend }}{\text { Earnings }}
$$

Insider ownership adalah pemegang saham dan pihak manajemen yang secara aktif ikut dalam pengambilan keputusan yaitu direktur dan komisaris (Wahidahwati 2002). Insider ownership diberi simbol INSD.Insider ownership menggunakan skala rasio yang diukur dengan cara membagi saham yang dimiliki direksi, komisaris, dan keluarganya dengan jumlah saham yang beredar (Khalid dan Rehman 2015).

$$
\text { INSD }=\frac{\text { Saham yang dimiliki direksi, komisaris, dan keluarganya }}{\text { Total jumlah saham yang beredar }}
$$


Ukuran perusahaan merupakan suatu skala dalam pengklasifikasian besar atau kecilnya suatu perusahaan (Sitanggang dan Agustina 2011).Dalam penelitian ini ukuran perusahaan diberi simbol SIZE. Variabel ini menggunakan skala rasio dan diukur dengan natural log of total assets (Khalid dan Rehman 2015).

$$
\text { SIZE = Ln (Total assets) }
$$

Profitabilitas yang diberi simbol PROF adalah kemampuan perusahaan dalam memperoleh laba dalam hubungannya dengan penjualan, total aktiva, maupun modal sendiri (Sartono 2001 dalam Bansaleng et al. 2014). Besaran profitabilitas diukur menggunakan skala rasio dan dihitung dengan rumus sebagai berikut (Khalid dan Rehman 2015):

$$
\text { PROF }=\frac{\text { Net Income }}{\text { Total Assets }}
$$

Leverage yang diberi simbol DTA merupakan penentuan komposisi modal, yaitu perbandingan antara hutang dan modal sendiri atau dengan kata lain leverage merupakan hasil atau akibat dari keputusan pendanaan (financial decision) yang intinya memilih apakah akan menggunakan hutang atau ekuitas untuk mendanai operasi perusahaan (Syamsuddin 2009 dalam Sulistyowati et al. 2014). Besaran leverage diukur dengan skala rasio dan dihitung dengan menggunakan rumus (Kazucu 2015):

$$
\text { DTA }=\frac{\text { Total Liabilities }}{\text { Total Assets }}
$$

Likuiditas diberi simbol CR digunakan untuk mengetahui kemampuan perusahaan melunasi kewajiban jangka pendek. Likuiditas diukur menggunakan indikator current ratio. Indikator ini menunjukkan kas dan setara kas relatif terhadap total aset (Kazucu 2015). Likuiditas diukur berdasarkan skala rasio dengan membagi current assets dengan current liabilities (Kazucu 2015).

$$
\mathrm{CR}=\frac{\text { Current Assets }}{\text { Current Liabilities }}
$$

Earnings per share yang diberi simbol EPS merupakan total keuntungan yang diperoleh investor untuk setiap lembar sahamnya. Menurut PSAK 56 (2014) besaran EPS dihitung dengan membagi laba rugi yang dapat diatribusikan kepada pemegang saham biasa entitas induk (pembilang) dengan jumlah rata-rata tertimbang saham biasa yang beredar (penyebut) dalam suatu periode. EPS diukur menggunakan skala rasio.

Price to book ratio yang diberi simbol PB menggambarkan seberapa besar pasar menghargai nilai buku suatu saham. Price to book ratio diukur dengan menggunakan skala rasio dan dihitung dengan cara membagi market capitalization dengan book value (Kazucu 2015). Market capitalization diukur dari harga pasar perlembar saham biasa dan book value diukur dengan cara membagi ekuitas saham biasa dengan jumlah saham yang beredar (Sumanti dan Mangantar 2015). Sehingga price to book ratio dapat diukur dengan rumus (Kazucu 2015):

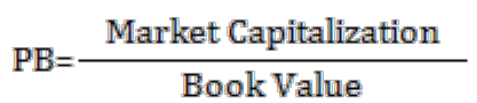

Besaran book value diukur dengan rumus:

Book Value $=\frac{\text { Ekuitas saham biasa }}{\text { Jumlah saham yang beredar }}$ 


\section{HASIL PENELITIAN}

Tabel 2

Hasil Analisis Statistik Deskriptif

\begin{tabular}{lrrrrr}
\hline & $N$ & \multicolumn{1}{c}{ Minimum } & \multicolumn{1}{c}{ Maximum } & \multicolumn{1}{c}{ Mean } & \multicolumn{1}{c}{ Std. Deviation } \\
\hline DP & 153 & 0,01609 & 0,99987 & 0,3704418 & 0,18360836 \\
INSD & 153 & 0,0000002 & 0,4083000 & 0,025575221 & 0,0664337712 \\
SIZE & 153 & 25,57957 & 33,09498 & 29,1754836 & 1,64249599 \\
PROF & 153 & 0,00203 & 0,40377 & 0,0927784 & 0,07467139 \\
DTA & 153 & 0,13059 & 0,76934 & 0,4444145 & 0,18121221 \\
CR & 153 & 0,38961 & 9,71692 & 2,2397175 & 1,60220293 \\
EPS & 153 & 3,71 & 4300,26 & 284,6392 & 557,58492 \\
PB & 153 & 0,31835 & 53,59006 & 3,8657846 & 6,53813408 \\
\hline
\end{tabular}

Sumber: Hasil pengolahan data SPSS versi 19

Tabel 3

Hasil Uji Hipotesis

\begin{tabular}{lrrl}
\hline \multicolumn{1}{c}{ Variabel } & B & \multicolumn{1}{c}{ Sig. } & \multicolumn{1}{c}{ Keterangan } \\
\hline (Constant) & $-0,535$ & 0,020 & \\
INSD & 0,083 & 0,644 & $\mathrm{Ha}_{1}$ Tidak Dapat Diterima \\
SIZE & 0,031 & 0,000 & $\mathrm{Ha}_{2}$ Diterima \\
PROF & 0,280 & 0,349 & $\mathrm{Ha}_{3}$ Tidak Dapat Diterima \\
DTA & $-0,197$ & 0,039 & $\mathrm{Ha}_{4}$ Diterima \\
CR & 0,007 & 0,473 & $\mathrm{Ha}_{5}$ Tidak Dapat Diterima \\
EPS & $-4,942 \mathrm{E}-5$ & 0,030 & $\mathrm{Ha}_{6}$ Diterima \\
PB & 0,014 & 0,000 & $\mathrm{Ha}_{7}$ Diterima \\
\hline
\end{tabular}

R 0,679, AdjR 20,435, F 17,713 Sig. 0.000

Sumber: Hasil pengolahan data SPSS versi 19

Insider ownership (INSD) memiliki nilai signifikansi sebesar 0,644 nilai ini lebih besar dari $a=0,05$. Hal ini menunjukkan bahwa tidak terdapat pengaruh insider ownership secara signifikan terhadap kebijakan dividen sehingga hipotesis alternatif pertama $\left(\mathrm{Ha}_{1}\right)$ tidak dapat diterima. Presentase jumlah kepemilikan saham manajerial dan kekuatan pihak manajer yang relatif kecil menyebabkan pemegang saham atau investor tidak mengkhawatirkan perilaku mereka secara berlebihan (Rahmawati 2014).

Ukuran perusahaan (SIZE) memiliki nilai signifikansi sebesar 0,000 nilai ini lebih kecil dari $a=0,05$. Hal ini menunjukkan bahwa terdapat pengaruh ukuran perusahaan secara signifikan terhadap kebijakan dividen sehingga hipotesis alternatif kedua $\left(\mathrm{Ha}_{2}\right)$ dapat diterima. Kemudian berdasarkan persamaan regresi terlihat bahwa koefisien untuk ukuran perusahaan bernilai positif $(0,031)$, sehingga dapat diartikan bahwa pengaruh yang diberikan oleh variabel ukuran perusahaan terhadap kebijakan dividen adalah positif. Hal ini berarti semakin besar ukuran perusahaan maka tingkat kedewasaan perusahaan tersebut akan bertambah dengan kinerja arus kas perusahaan yang positif sehingga dapat mensejahterakan pemegang 
saham perusahaan dengan cara membagikan dividen.

Profitabilitas (PROF) memiliki nilai signifikansi sebesar 0,349 nilai ini lebih besar dari $a=0,05$. Hal ini menunjukkan bahwa tidak terdapat pengaruh profitabilitas secara signifikan terhadap kebijakan dividen sehingga hipotesis alternatif ketiga $\left(\mathrm{Ha}_{3}\right)$ tidak dapat diterima. $\mathrm{Hal}$ ini didukung dengan teori yang mengatakan bahwa perusahaan akan mengalokasikan laba untuk kegiatan investasi yang menghasilkan return lebih tinggi dari return yang diharapkan.

Leverage (DTA) memiliki nilai signifikansi sebesar 0,039 nilai ini lebih kecil dari $\alpha=0,05$. $\mathrm{Hal}$ ini menunjukkan bahwa terdapat pengaruh leverage secara signifikan terhadap kebijakan dividen sehingga hipotesis alternatif keempat $\left(\mathrm{Ha}_{4}\right)$ dapat diterima. Kemudian berdasarkan persamaan regresi terlihat bahwa koefisien untuk leverage bernilai negatif $(-0,197)$, sehingga dapat diartikan bahwa pengaruh yang diberikan oleh variabel leverage terhadap kebijakan dividen adalah negatif. Hubungan negatif dengan kebijakan dividen menunjukkan bahwa perusahaan yang memiliki struktur pendanaan yang berasal dari hutang akan lebih memperhatikan penggunaan laba ditahan untuk dapat memenuhi kewajibannya dalam melunasi hutang tersebut sehingga mempengaruhi jumlah dividen yang dibagikan kepada pemegang saham atau investor.

Likuiditas (CR) memiliki nilai signifikansi sebesar 0,473 nilai ini lebih besar dari $a=0,05$. $\mathrm{Hal}$ ini menunjukkan bahwa tidak terdapat pengaruh likuiditas secara signifikan terhadap kebijakan dividen sehingga hipotesis alternatif kelima (Has) tidak dapat diterima. Hal ini disebabkan karena perusahaan dalam membagikan dividen tidak hanya memperhatikan kondisi likuiditas perusahaan saja tetapi juga memperhatikan lingkungan eksternal perusahaan (Sitanggang dan Agustina 2011).

Earnings per share (EPS) memiliki nilai signifikansi sebesar 0,030 nilai ini lebih kecil dari $a=0,05$. Hal ini menunjukkan bahwa terdapat pengaruh earnings per share secara signifikan terhadap kebijakan dividen sehingga hipotesis alternatif keenam $\left(\mathrm{Ha}_{6}\right)$ dapat diterima. Kemudian berdasarkan persamaan regresi terlihat bahwa koefisien untuk earnings per share bernilai negatif $(-4,942 \mathrm{E}-5)$, sehingga dapat diartikan bahwa pengaruh yang diberikan oleh variabel earnings per share terhadap kebijakan dividen adalah negatif. Efek negatif dari earnings per share masih dapat ditafsirkan sebagai perusahaan dengan pendapatan tinggi (rendah) cenderung menurun (meningkat) payout ratio nya (besarnya dividen relatif dari laba) (Kazucu 2015).

Price to book ratio (PB) memiliki nilai signifikansi sebesar 0,000 nilai ini lebih kecil dari $a=0,05$. Hal ini menunjukkan bahwa terdapat pengaruh price to book ratio secara signifikan terhadap kebijakan dividen sehingga hipotesis alternatif ketujuh $\left(\mathrm{Ha}_{7}\right)$ dapat diterima. Kemudian berdasarkan persamaan regresi terlihat bahwa koefisien untuk price to book ratio bernilai positif $(0,014)$, sehingga dapat diartikan bahwa pengaruh yang diberikan oleh variabel price to book ratio terhadap kebijakan dividen adalah positif. Price to book ratio menjelaskan kesempatan peluang investasi perusahaan, saat price to book ratio naik, maka peluang investasi juga naik. Perusahaan dengan peluang investasi yang tinggi akan membayar dividen lebih untuk menarik investor dan untuk meningkatkan kepercayaan pemegang saham kepada perusahaan (Damayanti dan Martiningtiyas 2014).

\section{PENUTUP}

Berdasarkan hasil penelitian ini dapat diperoleh kesimpulan sebagai berikut ukuran perusahaan, leverage, earnings per share dan price to book ratio memiliki pengaruh signifikan terhadap kebijakan dividen sementara insider ownership, profitabilitas dan likuiditas tidak memiliki pengaruh terhadap kebijakan dividen. Keterbatasan yang mungkin mempengaruhi hasil penelitian yaitu periode penelitian yang 
digunakan dalam melakukan pengujian hanya mencakup 3 tahun yaitu dari tahun 2012 sampai dengan tahun 2014. Penelitian ini hanya menggunakan Tujuh variabel independen saja, yaitu: insider ownership, ukuran perusahaan, profitabilitas, leverage, likuiditas, earnings per share dan price to book ratio. Dengan demikian masih terdapat variabel-variabel independen lain yang mungkin dapat mempengaruhi kebijakan dividen perusahaan. Adapun rekomendasi yang diberikan peneliti untuk penelitian selanjutnya sebaiknya menambah rentang waktu penelitian, sehingga dapat menjelaskan fenomena yang lebih menyeluruh. Penelitian selanjutnya diharapkan dapat menambah variabel lain yang belum dimasukan dalam penelitian ini seperti kepemilikan institusional, investasi, free cash flow, dan pertumbuhan perusahaan. 


\section{REFERENSI:}

Abdullah, Hilmi dan Ricki Fanani Agaki. 2014. Pengaruh Earning Per Share, Price Earning Ratio dan Price to Book Value terhadap Dividend Payout Ratio pada Perusahaan Pertambangan yang terdaftar di BEI Periode 2008-2011. DINAMIKA EKONOMIJurnal Ekonomi dan Bisnis, Vol. 7, No. 1, Maret 2014.

Amyas, Muhammad Arfan, dan Hasan Basri. 2014.Pengaruh Quick Ratio, Earning Per Share, danReturn on Investment terhadap Dividen Kas pada Perusahaan Manufaktur Sektor Food and Beverage yang Terdaftar di Bursa Efek Indonesia. Jurnal Akuntansi,Vol. 3, No. 1,Februari 2014.

Bansaleng, Resky D.V., Parengkuan Tommy, dan Ivonne S. Saerang. 2014. Kebijakan Hutang, Struktur Kepemilikan dan Profitabilitas terhadap Kebijakan Dividen pada Perusahaan Food and Beveragedi Bursa Efek Indonesia. Jurnal EMBA,Vol. 2, No.3, September 2014, Hal. 817-830.

Damayanti, Yustiara Izmi dan Catur Rahayu Martiningtiyas. 2014. Faktor-Faktor yang Mempengaruhi Kebijakan Pembayaran Dividen. E-Journal Manajemen Fakultas Ekonomi Universitas Trisakti, Vol. 1, No. 2, September 2014, Hal. 70-83.

Devi, Ni Putu Yunita dan Ni Made Adi Erawati. 2014. Pengaruh Kepemilikan Manajerial, Leverage, dan Ukuran Perusahaan pada Kebijakan Dividen Perusahaan Manufaktur. E-Jurnal Akuntansi Universitas Udayana, Vol. 9, No. 3, Hal. 709-716.

Gitman, Lawrence J., dan Chad J. Zutter. 2012. Principles of Managerial Finance $13^{\text {th }}$ Global Edition. England: Pearson.

Harahap, Aderina K. 2011. Pengaruh Earning Per Share dan Harga Saham terhadap Dividen Kas Perusahaan Manufaktur di Bursa Efek Indonesia Tahun 2006-2008. Jurnal Manajemen dan Bisnis,Vol. 1, No. 2,April 2011, Hal. 146-160.

Indahningrum, Rizka Putridan Ratih Handayani. 2009. Pengaruh Kepemilikan Manajerial, Kepemilikan Institusional, Dividen, Pertumbuhan Perusahaan, Free Cash Flowdan Profitabilitas terhadap Kebijakan Hutang Perusahaan. Jurnal Bisnis dan Akuntansi, Vol. 11, No.3, Desember 2009, Hal. 189-207.

Ikatan Akuntan Indonesia. 2014. Peryataan Standar Akuntansi Keuangan. Jakarta: Salemba Empat.

Karina, Maria Claudia dan Darsono. 2014. Pengaruh Struktur Kepemilikan dan Kinerja Perusahaan terhadap Kebijakan Dividen. Diponegoro Journal of Accounting, Vol. 3, No. 3, Hal. 1-10.

Kartika, Ni Putu Silva Mona dan Anak Agung Gede Suarjaya. 2015. Pengaruh Struktur Kepemilikan dan Kinerja Keuangan terhadap Kebijakan Dividen. E-Jurnal Manajemen Unud, Vol. 4, No. 11, Hal. 3766-3795.

Kazucu, Narman. 2015. Determinants of Dividend Policy: A Panel Data Analysis for Turkish Listed Firms. International Journal of Business and Management, Vol. 10, No. 11.

Khalid, Saniadan Mobeen Ur Rehman. 2015. Determination of Factors effecting the Dividend policy of Organizations.International Journal of Information, Business and Management, Vol.7, No. 3.

Mawarni, Luh Fajarini Indah dan Ni Made Dwi Ratnadi. 2014. Pengaruh Kesempatan Investasi, Leverage, dan Likuiditas pada Kebijakan Dividen Perusahaan Manufaktur yang Terdaftar di BEl. E-Jurnal Akuntansi Universitas Udayana, Vol. 9, No. 1, Oktober 2014, Hal. 200-208.

Rachmad, Anggie Noor dan Dul Muid. 2013. Pengaruh Struktur Kepemilikan, Leverage dan Return on Assets (ROA) terhadap Kebijakan Dividen (Studi Empiris pada Perusahaan Nonkeuangan yang Terdaftar di Bursa Efek Indonesia). Diponegoro Journal of Accounting, Vol. 2, No. 3, Juli 2013, Hal. 1-11.

Rahmawati, Ratna. 2014. Pengaruh Likuiditas Perusahaan, Hutang, Tingkat Pertumbuhan, dan Managerial Ownership terhadap Kebijakan Dividen pada Perusahaan Manufaktur di BEI Periode 2010-2012. Jurnal Manajemen Bisnis Indonesia, Vol. 3, Edisi 5.

Sekaran, Uma dant Roger Bougie. 2013. Research Methods for Business A Skill Building Approach, Sixth Edition. West Sussex: John Wiley \& Sons Ltd. 
Simanjuntak, Damaris dan Kiswanto. 2015. Determinan Kebijakan Dividen pada Perusahaan Manufaktur di Indonesia Tahun 2011-2013. Jurnal Dinamika Akuntansi, Vol. 7, No. 2, September 2015, Hal. 150-160.

Singhania, Monica dan Akshay Gupta. 2012.Determinants of Corporate Dividend Policy A Tobit Model Approach. SAGE Publications, Hal. 153-162.

Sitanggang, Vista Yuniarti dan Yeni Agustina. 2011. Faktor-Faktor yang Mempengaruhi Pembayaran Dividen pada Perusahaan Manufaktur yang Terdaftar di Bursa Efek Indonesia. Jurnal IImiah ESAI, Vol. 5, No. 3, Juli 2011.

Sulistyowati, Agnes, Suhadak, Achmad Husaini. 2014. Pengaruh Struktur Modal terhadap Kebijakan Dividend. Jurnal Administrasi Bisnis, Vol. 8, No. 2, Maret 2014.

Sumanti, Jorenza Chiquita dan Marjam Mangantar. 2015. Analisis Kepemilikan Manajerial, Kebijakan Hutang dan Profitabilitas terhadap Kebijakan Dividen dan Nilai Perusahaan pada Perusahaan Manufaktur yang Terdaftar di BEl. Jurnal EMBA, Vol. 3, No. 1, Maret 2015, Hal. 1141-1151.

Ulum, Akhmad Samsul. 2011. Peran Pengukuran Kinerja dalam Mendukung Good Governance dalam Perspektif Agency Theory. Jurnal Dinamika Akuntansi, Vol. 3, No. 1, Maret 2011, Hal. 60-66.

Wahidahwati. 2002. Pengaruh Kepemilikan Manajerial dan Kepemilikan Institusional pada Kebijakan Hutang Perusahaan: Sebuah Perspektif Theory Agency. Jurnal Riset Akuntansi Indonesia, Vol. 5, No. 1, Januari 2002, Hal. 1-16.

Wedhana, Niluh Ayu Novy Sajjana dan I Gusti Bagus Wiksuana. 2015. Determinasi Kebijakan Dividen PerusahaanPerusahaan Manufaktur yang Terdaftar di Bursa Efek Indonesia. E-Jurnal Manajemen Unud, Vol. 4, No. 11, Hal. 3962-3990.

Wicaksono, Santiko dan Mohamad Nasir. 2014. Faktor-Faktor yang Mempengaruhi Kebijakan Dividen pada Perusahaan Manufaktur yang Terdaftar di BEI Periode Tahun 2011-2013. Diponegoro Journal of Accounting, Vol. 3, No. 4, Hal. 1-13. 